\title{
STRUCTURAL RESULTS OF PROSTATECTOMY WITH REFERENCE TO METHODS OF ENUCLEATION
}

\author{
BASED ON A STUDY OF ONE HUNDRED AND THIRTY-SIX CASES *
}

\author{
FRANK HINMAN, A.B., M.D. \\ SAN FRANCISCO
}

A recent analysis of my own cases of prostatectomy ${ }^{1}$ shows a close relationship between functional and structural results and emphasizes the fact that good anatomic restoration is essential to a complete cure of the prostatism. The failure of good posterior urethral restoration and of preservation of sphincters and ejaculatory ducts may be the result of anatomic changes produced by the disease or by the surgical procedure. It is seldom that uncomplicated prostatism can so alter anatomic structures as to be incurable. Unsuccessful and incomplete enucleation of the hyperplastic mass is, however, one of the chief surgical errors that lead to immediate functional failure, or later, to recurrence of prostatism. A knowledge of the pathology of prostatic enlargement, with the anatomic changes that accompany it, and a careful consideration of these facts in relation to either the suprapubic or perineal method of enucleation are essential to an understanding of the structural defects peculiar, as well as common, to both. Such an understanding, if well founded, should reduce the frequency and gravity of structural defects surgically produced and lead in consequence to marked improvement in functional results.

\section{PATHCLOGY AND ANATOMIC CHANGES}

The facts regarding the anatomy and pathology may be briefly stated. Hyperplasia begins in the central group of glands in separate foci and probably never as a diffuse process. Numerous spheroidal tumors result, which tend to agglomerate, and in their growth condense the peripheral gland tissue by compression to form a pseudocapsule. It is inside this false capsule that surgical enucleation is performed. ${ }^{2}$ The posterior lobe is separated from the other lobes by

\footnotetext{
*Read before the Section on Urology at the Seventy-Second Annual Session of the American Medical Association, Boston, June, 1921.

1. Hinman, Frank: "Suprapubic versus Perineal Prostatectomy, a Comparative Study of Ninety Perineal and Thirty-Eight Suprapubic Cases," read before the American Urological Association, Montreal, June 2, 1921.

2. Freyer ("Clinical Lectures on Enlargement of the Prostate with a Description of the Author's Method of Total Enucleation of the Organ," William Ward Company, 1920) contends that he performs a complete pros-
} 
the connective tissue sheath carrying the ejaculatory ducts and apparently does not undergo hyperplastic changes, so that for all practical purposes all enlargements are prespermatic. Any peri-urethral group of glandular tissue of the middle, lateral or anterior lobes may be the initial focus of hyperplasia. ${ }^{3}$ These changes may also occur in the subcervical and subtrigonal groups and cause obstruction; but it is, indeed, rarely, if ever, that one sees enlargement of these groups without an associated enlargement of some of the chief lobes of the prostate. The type of enlargement will necessarily conform to the number and location of initial foci and their relative growth. All sorts of combinations have been observed; but the commonest is bilateral and middle lobe enlargement which is peri-urethral and more or less fused into one mass. The histopatho! ogy of this mass varies from an almost pure adenoma to myoma or fibroma ; but most frequently it is a mixed fibromyo-adenoma with the glandular element predominating. The more fibrous or muscular types are smaller, the former commonly complicated by or secondary to prostatitis, and both likely to be unassociated with a false capsule. An enlargement which has no false capsule or line of cleavage is recognized as difficult of enucleation. Growth

tatectomy. He bases his conclusion on the following evidence (p. 156) : "(1) The general conformation of the specimens removed by me indicated that they were entire prostates. (2) The absence of any palpable substance in the cavity that remained at the time of operation, as felt between a finger in this cavity and a finger in the rectum, a very thin membrane consisting merely of the bowel and sheath of rectovesical fascia lying between the points of the fingers. (3) The absence of any mass resembling prostatic tissue in the cases operated on, at any period after the operation, on examination by the finger in the rectum. (4) When the enlarged prostate projects prominently in the bladder the true capsule is at once reached on scraping through the mucous membrane covering it by the finger nail. (5) The absolute and complete relief of symptoms after operation. (6) But Mr. Thompson Walker has adduced the most cogent evidence of all by demonstrating that no prostatic tissue is found in specimens removed from the bodies of persons on whom the operation had been performed during life." It is rather hazardous to disagree with two such eminent authorities, nevertheless, I do not hesitate to do so. For all practical purposes, complete enucleation of the prespermatic portion in cases of large glands is effected by the Fuller-Freyer as well as by the radical en masse perineal method. The false capsule of compressed nonhyperplastic gland tissue is insignificant in these cases. In smaller enlargements, however, there is a very visible and evident false capsule composed of more or less normal gland tissue. This can be clearly demonstrated in postmortem examinations of unoperated cases of prostatism. A complete enucleation would remove the vermontanum and terminal portions of the ejaculatory ducts. This, I believe, is often done suprapubically, as has been demonstrated by a number of our perineal specimens before we appreciated the importance of incision of the supramontane urethra.

3. Freyer conceives the prostate as formed of two lateral lobes. 


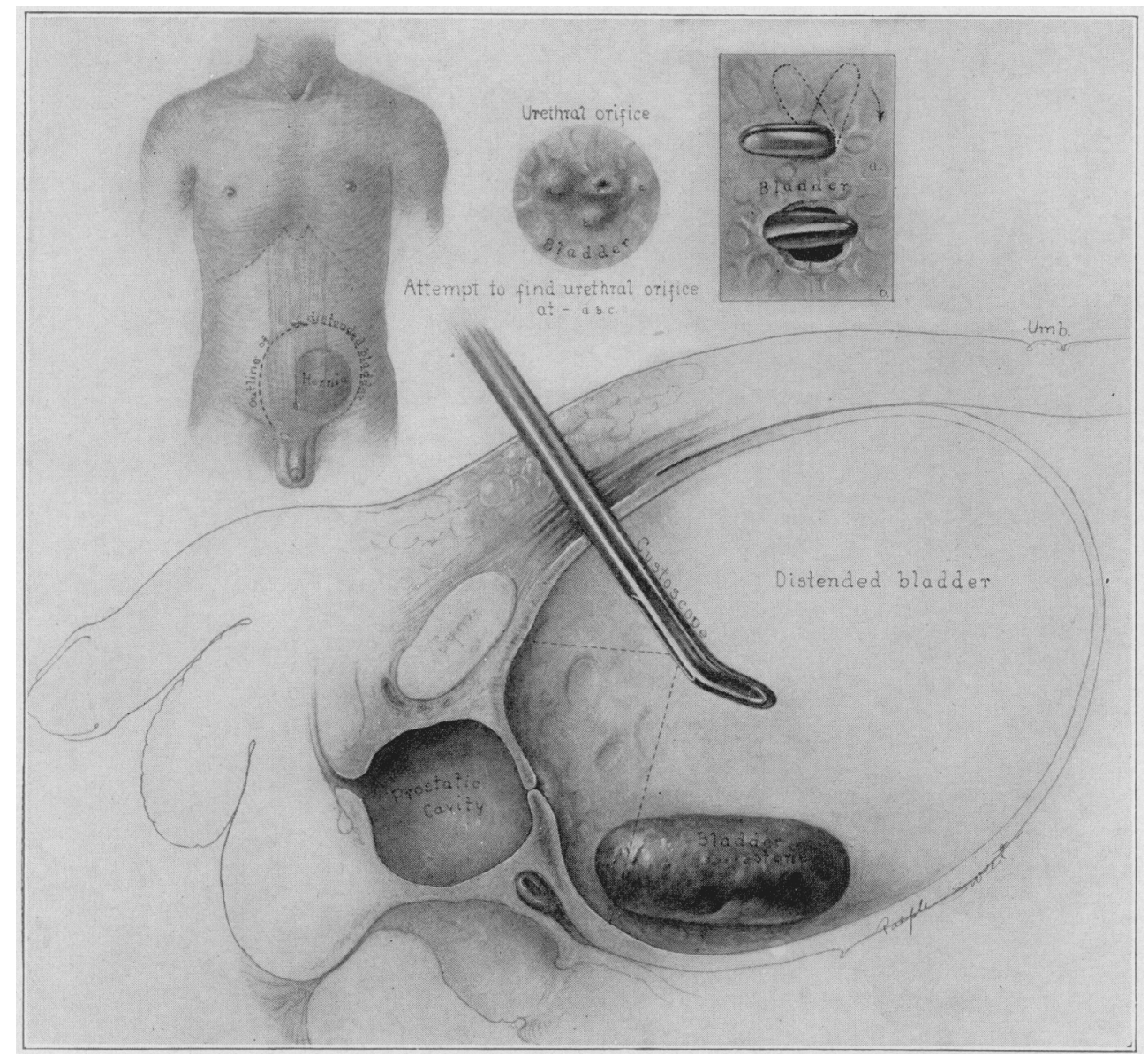

Fig. 1.-Diagrammatic representation of conditions as found in a man, aged 74 , five years after suprapubic prostatectomy. He had never voided through the urethra since operation and had worn a suprapubic tube for five years. Repeated previous attempts to catheterize or dilate the urethra were unsuccessful. There were marked pyuria and renal insufficiency; a very large abdominal hernia through the scar of the suprapubic incision. There was no suspicion or evidence of cancer. Cystogram revealed double cavity, and it was at first thought that we were dealing with a diverticulum. Cystoscopically a very large prostatic cavity with an orifice that closely simulated the mouth of a diverticulum was found, through which the shaft of the instrument could be passed with difficulty. The bladder was markedly dilated and contained a large stone. Passing the cystoscope through the suprapubic sinus, a lithotrite could be made to engage at the contracted vesical orifice through the urethra (as shown in inset) and the stone was crushed under cystoscopic control. Young's punch instrument was inserted in the same way and the vesical neck contracture enlarged (inset $a$ and $b$ ). 
follows the line of least resistance intravesically inside the internal sphincter, and with large glands, the internal sphincter may be much dilated. The supramontane portion of the urethra is elongated and distorted in accordance with the type of enlargement. The verumontanum and ejaculatory ducts are pressed posteriorly, and the inframontane portion of the prostatic urethra with the external sphincter is undisturbed. What problems with reference to the enucleation of this hyperplastic mass from its prostatic bed clo these facts present to the surgeon?

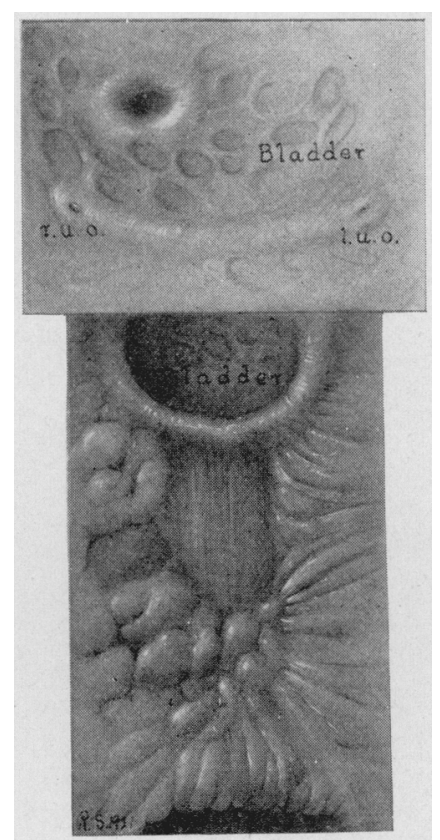

Fig. 2.--Urethroscopic appearance of prostatic urethra four years after suprapubic prostatectomy; large granular and nodular carity with dilated vesical orifice.

\section{METHODS OF ENUCLEATION}

Suprapubic enucleation is commonly a one-piece removal performed in one of two ways : Intra-urethrally or extra-urethrally; but the hyperplastic mass is sometimes removed in separate pieces either way. Intra-urethral en masse enucleation has been performed by us by forcing a finger back into the urethra and tearing it anteriorly. By blunt dissection on this line of cleavage, the hyperplastic mass is freed from within outward. In a few cases, we have made an annular or linear incision of the mucosa over the intravesical mass as an entering wedge for extra-urethral enucleation, from without inward, outside the urethra. 
The extra-urethral would seem to be a method better suited to surgery, although more difficult, and probably more often secures a complete removal. Whenever the gland is not brought away in one piece, it is sometimes difficult to determine whether spheroids remain, even with bimanual palpation with the finger in the rectum, which few surgeons practice because of danger of sepsis. Any of these procedures must be performed through the internal sphincter, which is thereby dilated and sometimes destroyed. The supramontane portion of the prostatic urethra is torn or more commonly completely removed. Tags and flaps

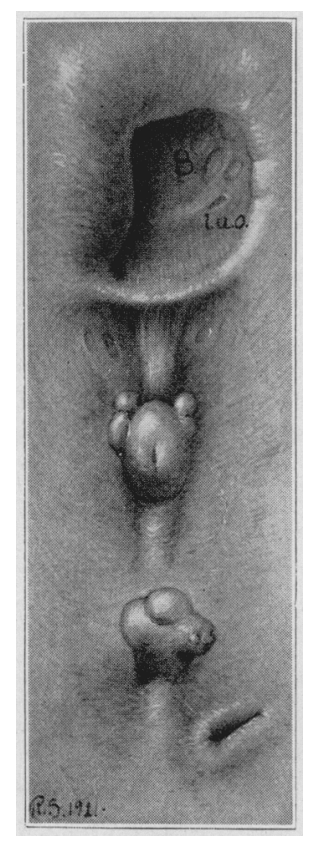

Fig. 3.-Urethroscopic appearance of prostatic urethra two years after perineal prostatectomy; persistent nodule at right side of vesical orifice; tags in prostatic urethra and small sinus persisting at site of perineal fistula which has been permanently closed. The only functional disturbance is nycturia.

of mucosa are generally left at the prostatic margin or cavity. The prostatic cavity is packed for hemostasis, thus tending to perpetuate posterior urethral elongation and cavity formation.

Perineal enucleation, if Young's technic is followed, preserves the prostatic urethra throughout, and rarely is either the internal sphincter or vesical mucosa disturbed. The bilateral posterior lobe incisions render possible good preservation of the ejaculatory ducts and verumontanum. When properly performed, the external sphincter remains untouched. The gland is enucleated in separate portions, first the right, 


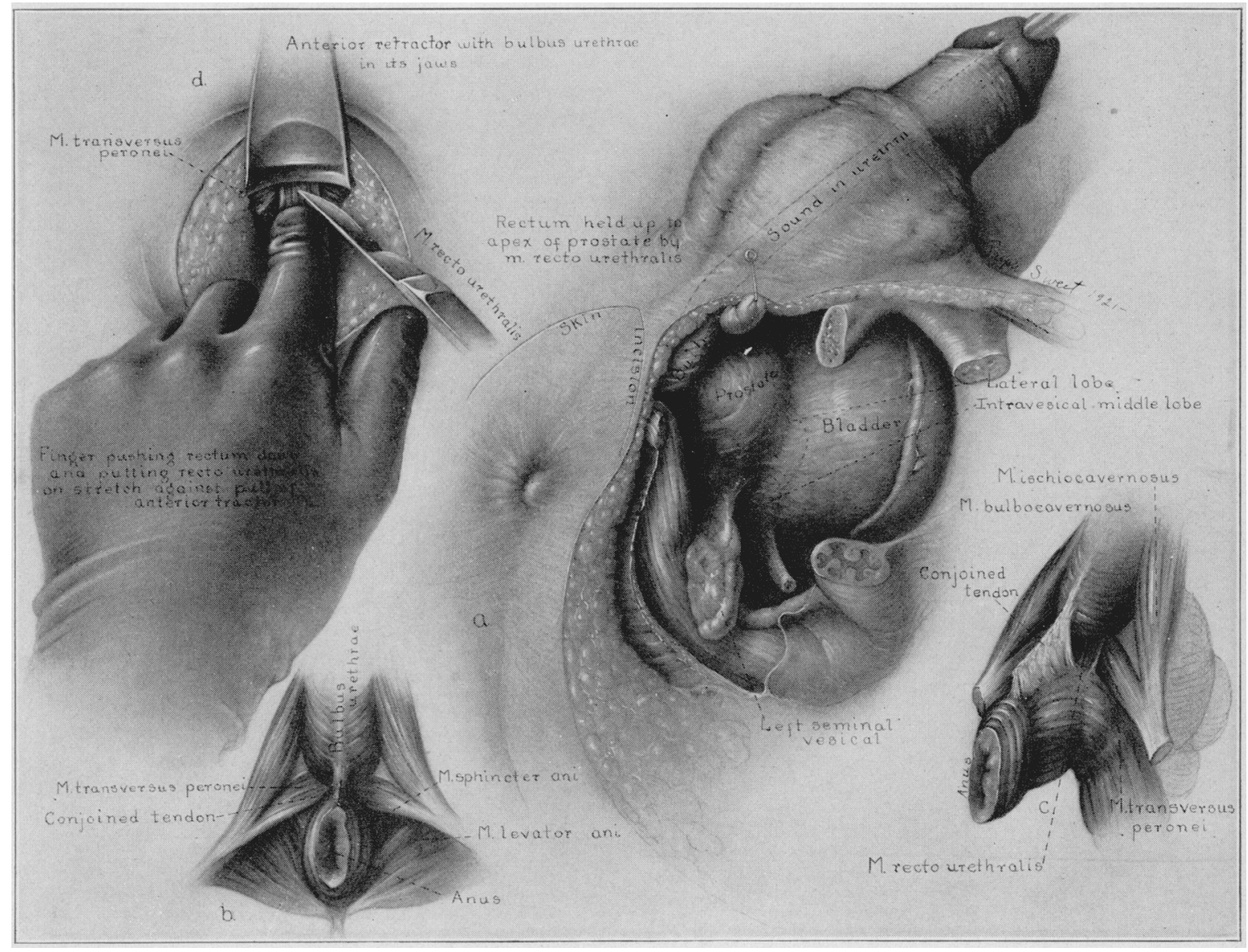

Fig. 4.- The all important recto-urethroprostatic juncture: a, close apposition of bulbus urethrae, triangular ligaments carrying the external sphincter, rectum and apex of the prostate; $b$, exposure of the membranous urethra keeping close to the rectum in order to preserve the perineal union and not injure the hull, transversus perinei or triangular ligaments with the external sphincter; $c$, correct division of the conjoined tendon and recto-urethralis muscle; careless dissection may injure rectum or perineal union; $d$, separation of rectum from apex of prostate is best effected by knife and blunt dissection putting the recto-urethralis muscle on stretch by pressing rectum down with finger and pulling the buib with the external sphincter and triangular ligaments up with anterior retractor. 


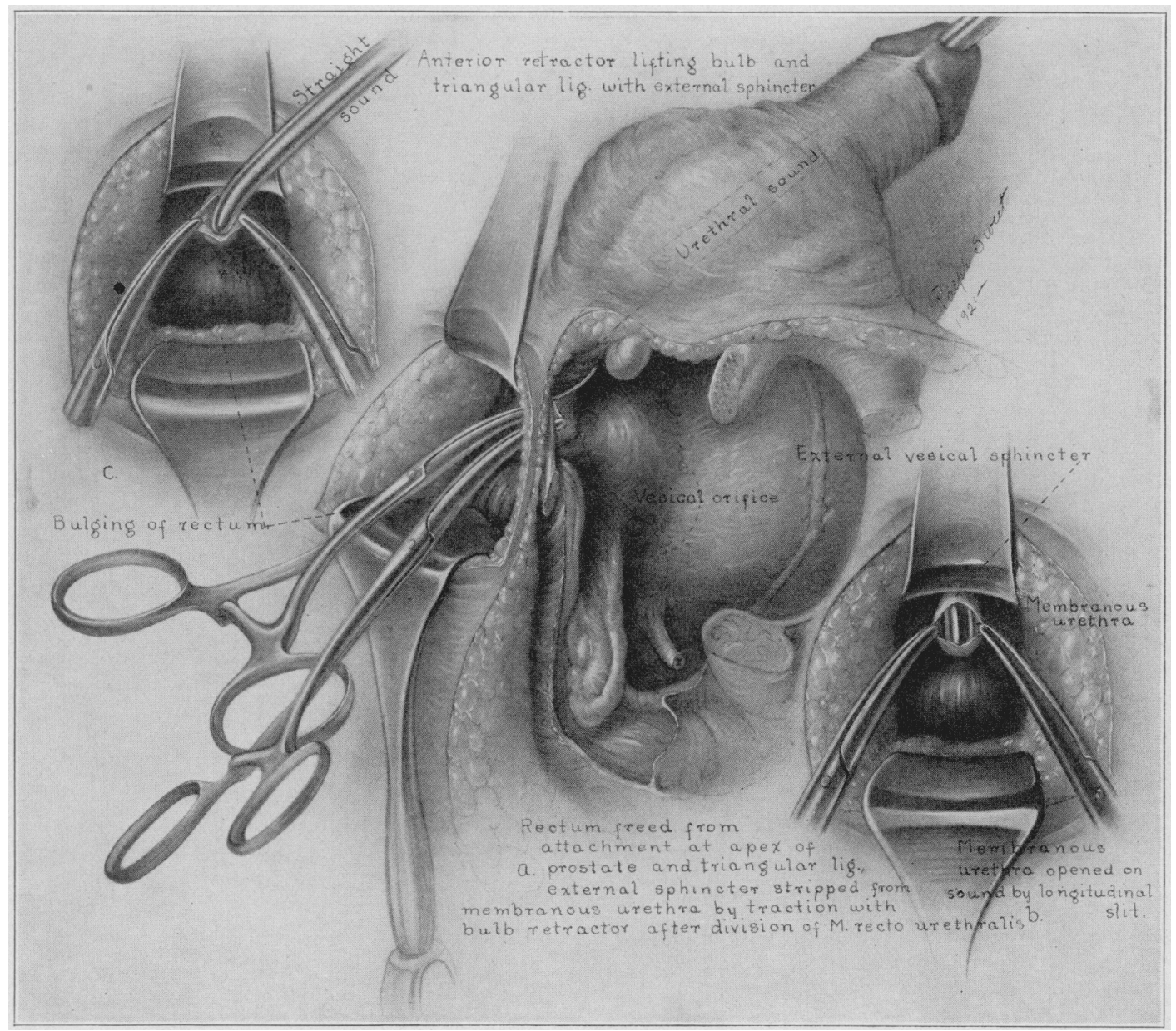

Fig. 5.-Exposure of the membranous urethra: $a$. clamps placed on each lip of the longitudinal incision; the rectum still in close contact with the apex of the prostate $(b): c$, the urethral sound removed by an assistant and the straight sound inserted into the bladder through the incision, acting as a control and guide to the insertion of Young's prostatic tractor. 
then the left lobe, or vice versa, and an anterior or middle enlargement is finally delivered through one or the other of the lateral incisions. Successfully executed, the method is surgically ideal. Technical difficulties are increased with the ring type, and very large hyperplasias and these difficulties, probably more than the anatomic difficulties of approach, appeal to me as the important factors leading to the general disrepute of a ferfect surgical procedure.

\section{STRUCTLRAL DEFECTS OF SUPRAPULIC AND IERINEAL PROSTATECTOMY}

The common defect in structure following suprapubic enucleation is a failure of restoration of the prostatic urethra, which is replaced by a larger or smaller cavity, either infundibular or spindle shaped, according to its association with a widely dilated or contracted vesical neck (Figs. 1 and 2). Incomplete enucleation may leave nodules or large lobes at various parts of the cavity or neck, which may be so placed as to impair sphincteric action, resulting in dribbling, or, to prevent complete evacuation, resulting in continued frequency and urinary infection. Tags of mucous membrane or other tissue left in the prostatic ensemble or about the neck may repair in such a way as to act as an irritant or even a ball valve polyp, producing marked disturbances of urination.

Cavity formation rarely follows the perineal operation; but structural defects at the neck from the presence of nodules or tags are common, and unless the operator is familiar with the perineal method, nodular remnants, due to incomplete removal of all the hyperplastic mass, are more likely to remain than after the suprapubic operation (Fig. 3). These cause functional disturbances and may lead to recurrence of prostatism. Deep fissure or sulcus formation is also not uncommon, particularly in cases after removal of very large glands, and, in such cases also, mucosal plication may lead 10 obstruction to instrumentation as well as urination.

\section{MODIFIED METHOD OF PERINEAL ENUCLEATION}

The radical en masse enucleation as usually done suprapubically insures more certain and complete removal of the hyperplastic tissue than does the lobular removal by the perineal method. This fact raises the question as to whether block enucleation through the perineum might not secure cleaner and more complete removal and at the same time give better structural restoration, or whether a one-piece perineal enucleation with divulsion of the prostatic urethra might leave, as is common suprapubically, a large prostatic cavity, or finally whether such radical removal would be more likely to injure the ejaculatory 


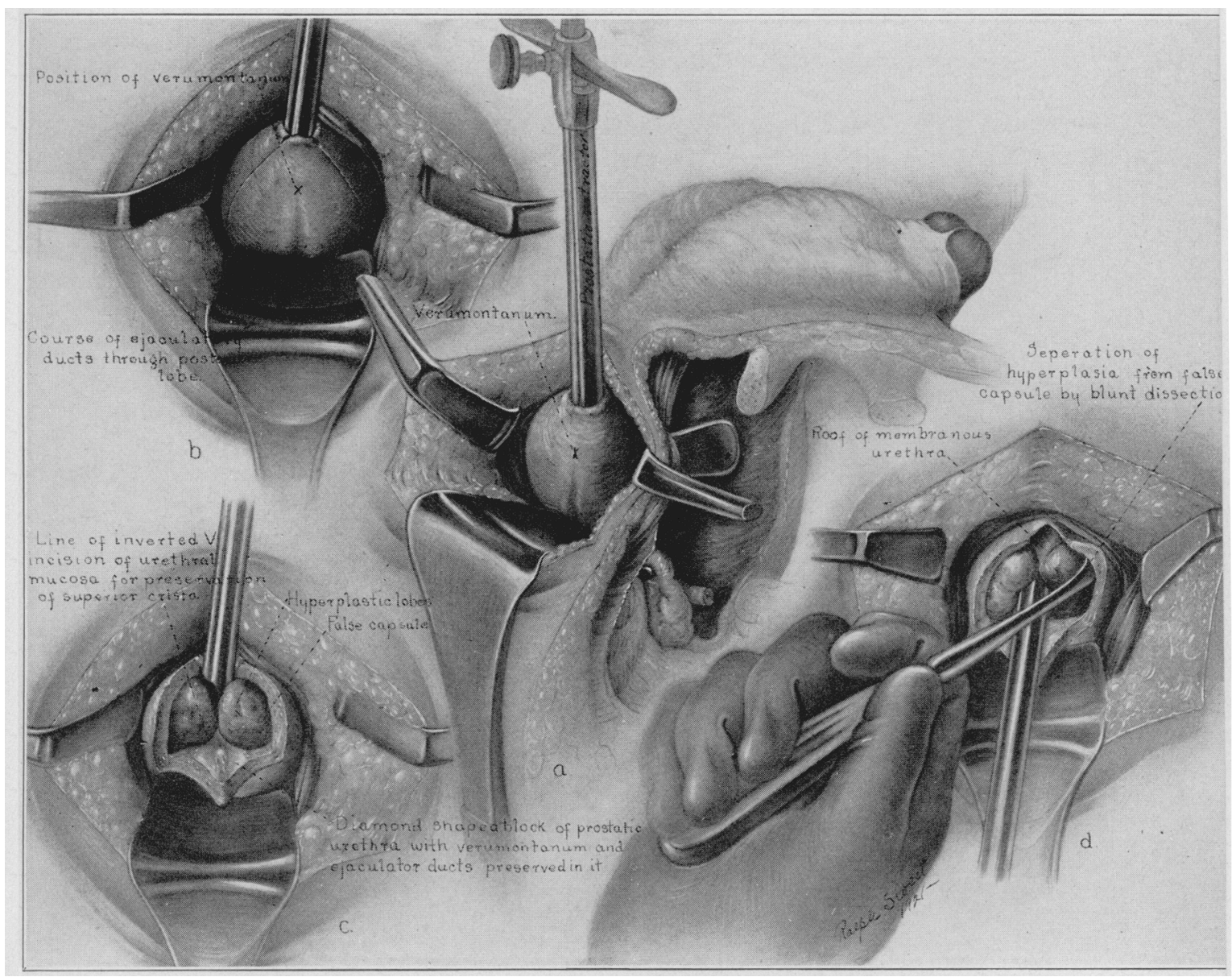

fir. 6. - Method of cumcleation: a, the rectum has been dissected from the posterior surface of the prosta1 along line of fascia of Ienonvillier and is held out of the way by the deep posteriot retractor: the prostat mass is drawn down into the wound by the prostatic tractor, and ready for incision for enucleation; $b$, a wic inverted $V$ incision is made in the posterior lobe well into the hyperplastic mass; $c$, the pointed flap of posteric lobe when thrown back exposes the verumontanum and ejaculatory duct orifices. A diamond shaped block $c$ prostatic urethra is preserved by a second inverted $V$ incision of the mucosa with its apex just above th superior crista of the verumontanum: $d$, depression of the prostatic tractor exposes the roof of the men branous urethra which is divided with scissors so as to free completely the urethral end of the prostat urethra. The hyperplastic mass is freed en masse by blunt dissection, or adhesions can be accurately divide with knite or scissors. 
ducts. In order to arrive at an answer, we have now performed twenty-five perineal operations by a modification of Young's methot of enucleation, whereby the hyperplastic gland may be removed in one piece just as is done suprapubically. The one purpose is to secure complete and clean removal and at the same time preserve the ejaculatory ducts, the verumontanum and both sphincters as effectively as by the old method. No attempt is made to preserve the supramontane portion of the urethra.

The technic of conservative perineal prostatectomy as practiced and taught by Hugh $\mathrm{H}$. Young is followed up to the incision of the posterior lobe for the purpose of enucleation. The anatomic difficulties of approach of this operation are mastered with a thorough knowledge of the recto-urethro-prostatic juncture (Fig. 4). Injuries of the rectum or external sphincter never follow a properly performed perineal exposure. ${ }^{4}$ The urethra at its membranous portion is opened by a longitudinal incision (Fig. 5), and after the insertion of the prostatic tractor, the rectum can easily be separated frum the prostate along the line of Dénonvillier's fascia (Fig. $6 a$ ). After the prostate is well exposed, instead of making two lateral incisions into it, after Young's technic and as was done in our first sixty-five cases, an inverted $\mathrm{V}$ incision having a wide obtuse angle, the apex of which is at the opening into the membranous urethra, is used (Fig. 6b). This incision is deepened well into the lateral spheroids, or, if no lateral hyperplasia exists, is continued down through the urethral mucosa to the prostatic tractor (Fig. 6c). When so extended, it allows one to drop back the verumontanum and ejaculatory ducts in a triangular flap of the posterior lobe, thus giving wide exposure of the prostatic urethra (Fig. 6c). It is important now that the prostatic urethra above the verumontanum near the bladder be incised by another inverted $\mathrm{V}$ or elliptic cut so as to free the supramontane urethra completely from this flap portion (Fig. $6 c$ ), as otherwise the colliculus might be torn or mutilated by the manipulation to follow. Division of the roof of the membranous urethra with scissors (Fig. 6d) now frees the whole prespermatic portion. The hyperplastic mass can be easily and accurately dissected loose with perfect preservation of the internal sphincter (Fig. 7), and when the prostatic urethra has been divided at its vesical end with scissors or knife (Fig. 7b), this mass can be removed en masse on the shaft of the prostatic tractor (Fig. 7c). Tactile and visual inspection of the vesical neck is now easy, and tags or defects may be remedied by the proper procedure (Fig. 7d). Small

4. In ninety cases we have had but one rectal injury, caused by an inexperienced assistant holding the retractor so that its edge dug into the rectal wall. This fistula closed promptly and spontaneously. We have not one case of incontinence from injury to the external sphincter. 


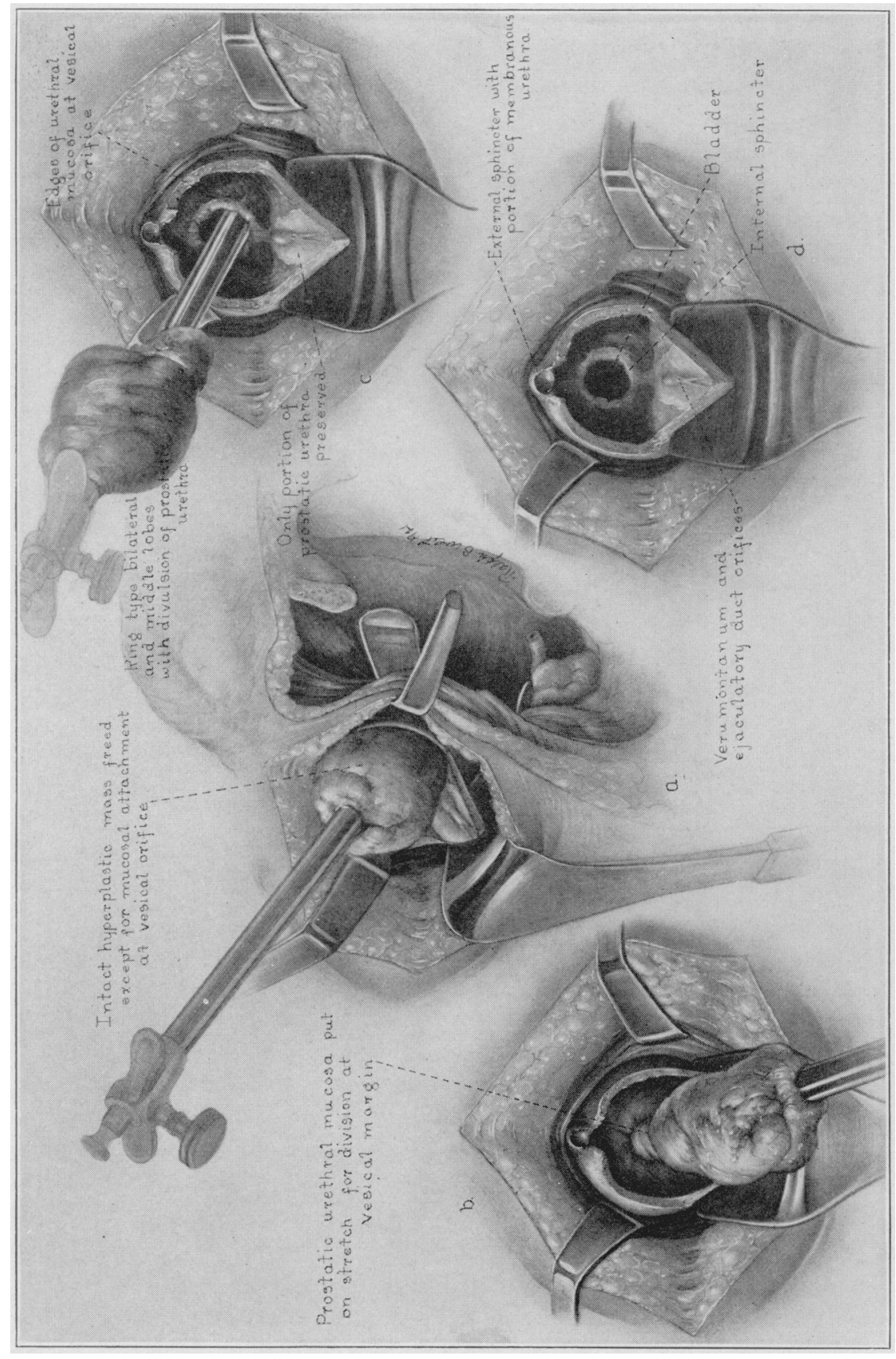

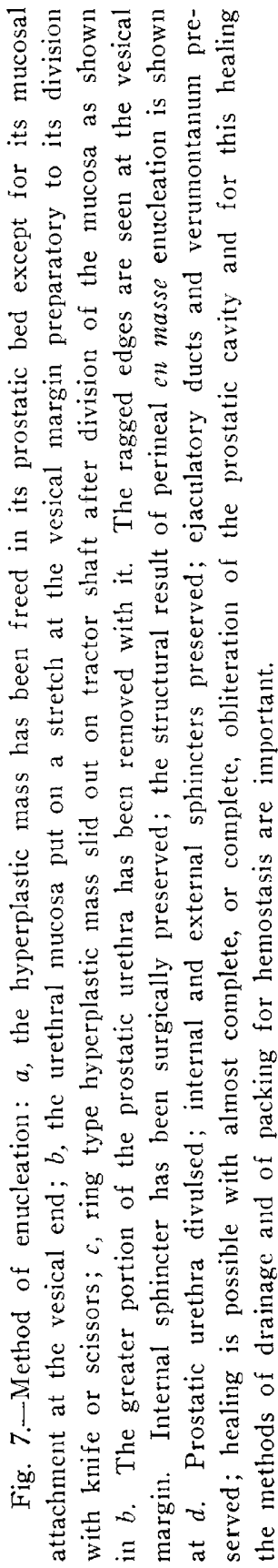


subcervical or intravesical lobes which failed to come away with the main mass can now be accurately and cleanly removed.

The enucleation having been completed, a catheter on a stilet is passed through the urethra by an assistant, and its end is inserted into the bladder alongside the tractor, which is then removed (Fig. 8). The catheter is thus placed for reestablishment of the urethra as is done in external urethrotomy. A second catheter is placed through the perineum into the bladder for the purpose of through-and-through irrigation. The prostatic cavity is lightly packed about the two catheters passing through it, with one strip of gauze (Fig. $8 b$ ), which is brought out with the perineal catheter at one side. The triangular flap of the posterior lobe, carrying the ejaculatory ducts and verumontanum, is replaced in position by a mattress suture of chromic gut on the side opposite the gauze and catheter (Fig. 8c). An infraprostatic gauze pack is placed for the purpose of cavity obliteration and hemostasis (Fig. 8d). Closure now follows the usual technic (Fig. 9.) The gauze and perineal catheter are removed after twenty-four hours. It is our custom to remove the prostatic pack first, and, if no bleeding follows, in one-half hour the infraprostatic pack with the perineal catheter is removed. If there is bleeding, it is readily controlled by pressure with hemostat against the infraprostatic pack, and repacking is not required. The urethral catheter is often left in from four to twelve days, and suction applied to it by a Connell apparatus or Davis bottle. In ten of the twenty-five cases the perineum remained dry after the second day and healed, to all practical purposes, by first intention.

\section{CCMMENT}

This type of inverted $\mathrm{V}$ incision of the posterior lobe is not new as it was used by Young in his earliest cases but has been replaced by two lateral incisions because it was thought that better anatomic preservation was thus possible. Any systematic effort for clean, complete removal of the enlarged prostatic mass in one piece through the perineum, however, has not been previously made. With medium-sized enlargements of glandular type, removal through lateral incisions is satisfactory, and remarkable preservation of the mucosal layer of the prostatic urethra, leaving the verumontanum and ejaculatory ducts intact, is possible. But in enucleating large glands, tears and extension of the lateral incisions to the membranous urethra almost invariably result, and this leaves a very narrow strip of tissue as the ejaculatory bridge. The ejaculatory ducts and verumontanum can be satisfactorily preserved with the $\mathrm{V}$ type of posterior lobe incision irrespective of the size and pathology of the hyperplasia. A good view of the vermontanum can always be had, and the necessary amount of mucosa for its preservation can be trimmed off with knife or scissors from the supra- 


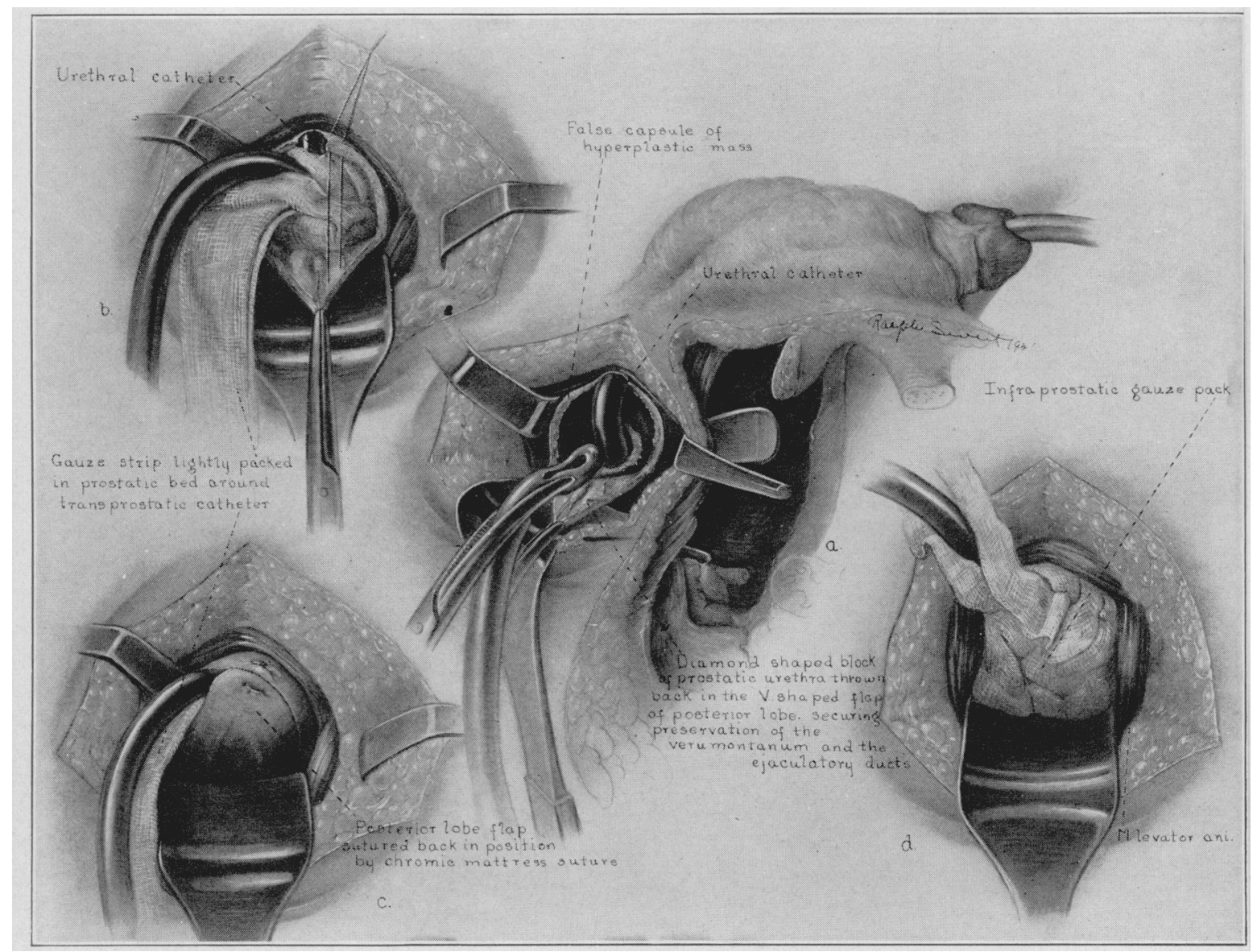

Fig. 8. - Method of catheter drainage and packing: $a$, urethral retention catheter is placed for vesical drainage and reestablishment of prostatic urethra. Perineal catheter is jlaced for drainage only; $b$, light. prostatic gauze pack in the prostatic hed for hemostasis; removed in twenty-four hours; $c$, closure of the prostatic flap by a mattress suture on the left with gauze and perineal catheter issuing through right sided slit; $d$, placement of a large or small infraprostatic gauze pack which is removed one-half hour after the prostatic gauze is removed provided there is no hemorrhage. 


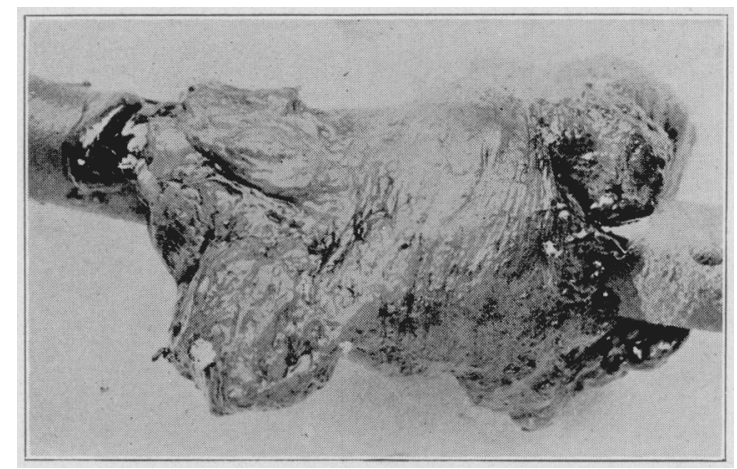

Fig. 10.-Ring type of bilateral and middle lobe enlargement removed in recent case through the perineum. Small fibromyo-adenoma enucleated en masse with complete preservation of colliculus and internal sphincter, but with removal of the supramontane portion of the prostatic urethra.

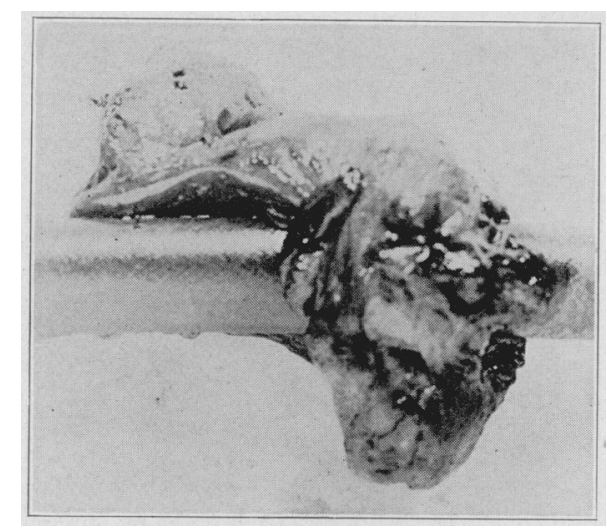

Fig. 11.-Side view, showing long mass of hyperplasia extending intravesically posteriorly to form the middle lobe.

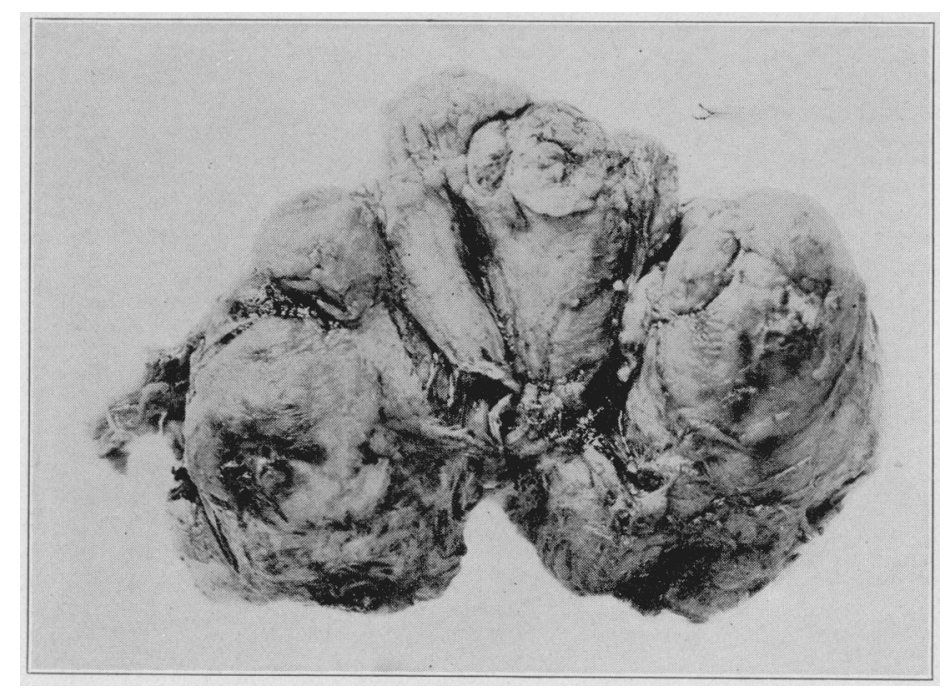

Fig. 12.-Large bilateral and middle lobe removed by way of the perineum in Case 13 (reported in accompanying table). Glandular type hyperplasia with clean-cut separation, anteriorly, of lateral lobes which fuse with middle lobe posteriorly. 


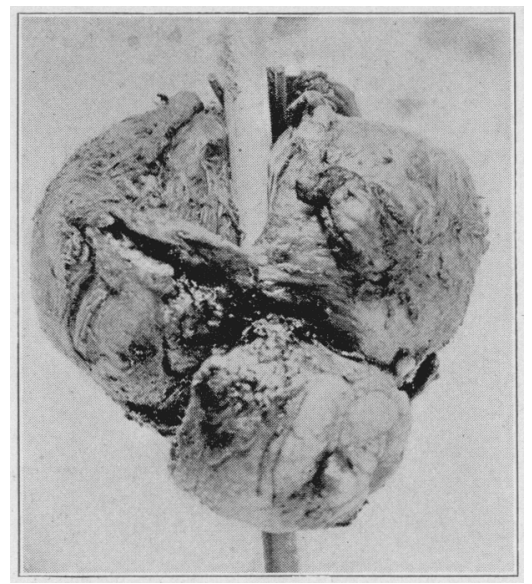

Fig. 13.-Large glandular ring type hyperplasia, enucleated intact by way of the perineum before the importance of incision of the supramontane portion of the prostatic urethra was appreciated. The colliculus and terminal portions of the ejaculatory ducts have been removed with the prostatic urethra.

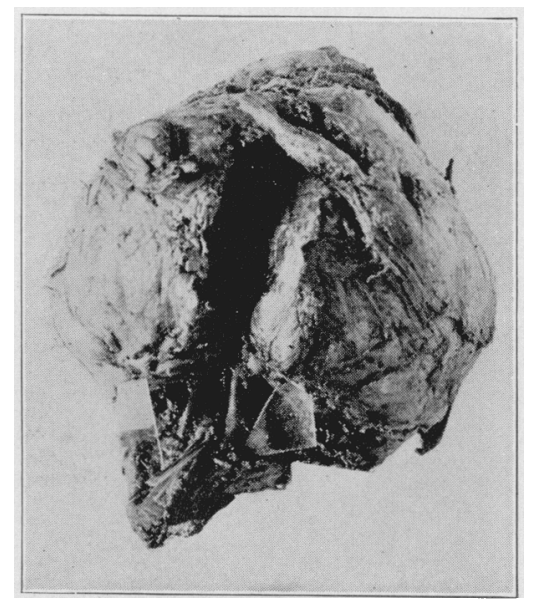

Fig. 14.-Posterior urethra spread apart to show verumontanum; same case as shown in Figure 13.

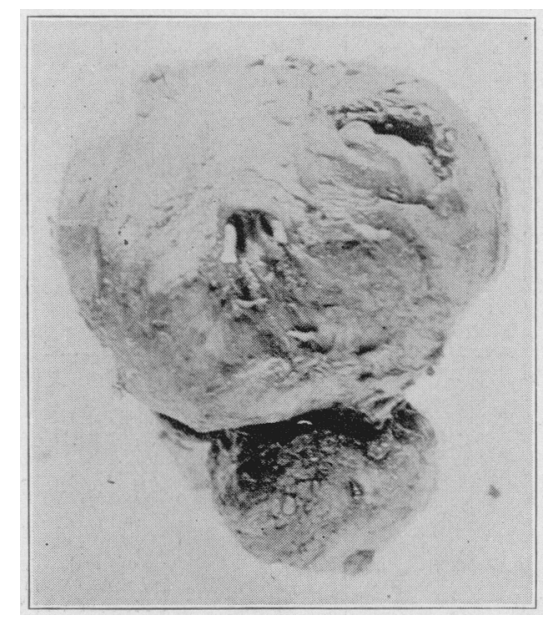

Fig. 15.-Posterior view showing distal ends of torn ejaculatory ducts; same ase as shown in Figure 13. 
Answers to QuestionnaIRes-

Serial number $\ldots \ldots \ldots \ldots \ldots \ldots \ldots \ldots \ldots \ldots$
$\begin{gathered}\text { Give the average number } \\ \text { during the day }\end{gathered}$

Do you get up at night to void?

Give the average number of times

Give the approximate time of night that

these voidings oceur
Do you have burning on urination?.....

Do you have hesitancy of urination?....

Do you have difficulty of urination?..... Do you have dribbling of urine?.

1. Is this at end of urination?.

2. Is this between urination?.

Do you have good control of urination? What is the eharacter of your urine:

Clear?

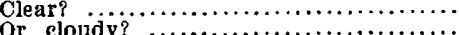

If. Regarding Your Sexual Life Since Operation:

1. Have you sexual desire?

2. Do you have erections?

A. Are they satisfactory?

B. Or unsatisfactory?

3. Have you had sexual intercourse?....

A. If not, has it been attempted?.....

B. Or not attempted? C. Give average frequency and char-
acter

4. Is ejaculation complete?

5. Do you have seminal discharge?........

III. General Condition:

1. Do you consider yourself cured of your prostatic trouble?

A. If you do not, please describe the character of present disability

2. How does your general health compare with what it was previous to operation?

Remark

\begin{tabular}{|c|c|c|c|c|c|}
\hline 1 & 2 & $\mathbf{3}$ & 4 & 5 & 6 \\
\hline 6 & 4 to 6 & $\begin{array}{l}\text { Every two to } \\
\text { four hours }\end{array}$ & 3 times & 4-5 times & $\begin{array}{c}\text { About every } \\
2 \text { nours }\end{array}$ \\
\hline Yes & $\begin{array}{l}\text { Never more } \\
\text { than once, } \\
\text { sometimes }\end{array}$ & Yes & Yes & No & Yes \\
\hline 2 & $\begin{array}{l}\text { none } \\
\ldots \ldots\end{array}$ & Twice & $\begin{array}{c}\text { Once or } \\
\text { twice }\end{array}$ & 0 & Three brs. \\
\hline $\begin{array}{l}2 \text { a.m. } \\
\text { No }\end{array}$ & $\begin{array}{c}2 \text { to } 4 \text { a.m. } \\
\text { or not at all } \\
\text { No }\end{array}$ & $\begin{array}{c}2: 30 \text { a. m. }-6 \text { a. m. } \\
\text { No }\end{array}$ & $\begin{array}{l}\text { Towards } \\
\text { morning } \\
\text { No }\end{array}$ & $\begin{array}{c}\cdots \cdots \\
0\end{array}$ & $\begin{array}{c}\cdots \cdots \\
\text { No }\end{array}$ \\
\hline No & No & Yes with little & No & 0 & No \\
\hline $\begin{array}{l}\text { No } \\
\text { Yes }\end{array}$ & $\begin{array}{l}\text { No } \\
\text { No }\end{array}$ & $\begin{array}{l}\text { None } \\
\text { Yes }\end{array}$ & $\begin{array}{l}\text { No } \\
\text { No }\end{array}$ & 0 & $\begin{array}{l}\text { Non } \\
\text { Non }\end{array}$ \\
\hline Yes & $\cdots \cdots$ & Yes, before and after & $\cdots \cdots$ & $\cdots \cdots$ & $\cdots \cdots$ \\
\hline & Yes & $\begin{array}{l}\text { exertion } \\
\text { Fxcept as above } \\
\text { stated }\end{array}$ & & $\begin{array}{l}\text { Very } \\
\text { good }\end{array}$ & \\
\hline $\begin{array}{l}\text { Clear } \\
\text {........... }\end{array}$ & $\begin{array}{l}\text { Clear } \\
\ldots \ldots \text {.... }\end{array}$ & slightily & $\begin{array}{l}\text { Clear } \\
\ldots \ldots \text {.... }\end{array}$ & $\begin{array}{l}\text { Yes } \\
\ldots \ldots . .\end{array}$ & $\begin{array}{l}\text { Clear } \\
\cdots . . .\end{array}$ \\
\hline Yes & Yes & Yes & No, not & Occasion- & Yes \\
\hline No & Yes & $\begin{array}{l}\text { No, my operation } \\
\text { completely emaseu- } \\
\text { lated me }\end{array}$ & No & No & $\begin{array}{c}\cdots \cdots \\
\text { Not } \\
\text { very }\end{array}$ \\
\hline & ....... & 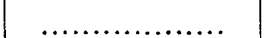 & ...... & ...... & Unsatis- \\
\hline No & Yes & If penetration is & Selđom & No & $\begin{array}{c}\text { actory } \\
\text { Yes }\end{array}$ \\
\hline Yes & $\ldots \ldots$ & $\begin{array}{l}\text { Attempted twiee since } \\
\text { leaving hos. Decidedly } \\
\text { unsatisfactory. There } \\
\text { was seminal discharge } \\
\text { but incomplete and } \\
\text { unsatisfactory }\end{array}$ & Seldom & No & $\ldots \ldots$ \\
\hline ..... & ....... & 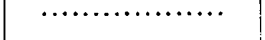 & $\cdots \cdots$ & $\cdots \cdots$ & $\cdots \cdots$ \\
\hline$\cdots \ldots \ldots$ & $\begin{array}{l}\text { Once in } \\
\text { two weeks } \\
\text { Yes } \\
\text { Yes }\end{array}$ & As stated sbove & No & $\dddot{\text { No }}$ & $\begin{array}{l}\cdots \cdots \\
\cdots \cdots \\
\cdots \cdots\end{array}$ \\
\hline $\begin{array}{l}\text { Yes. with ex- } \\
\text { ception of the } \\
\text { dripping }\end{array}$ & Yes & $\begin{array}{l}\text { Yes, as far as } \\
\text { ability to void } \\
\text { urine }\end{array}$ & Yes & Yes & Yes \\
\hline $\begin{array}{l}\text {.......... } \\
\text { Good, only I } \\
\text { am suffering } \\
\text { from neuritis } \\
\text { which I had be- } \\
\text { fore operation } \\
\text { and I get pretty } \\
\text { bad at times } \\
\text { which you can } \\
\text { see by my writ- } \\
\text { ing as I can } \\
\text { hardly hold } \\
\text { my pen }\end{array}$ & $\begin{array}{l}\text { Loss of sex- } \\
\text { ual power } \\
\text { very } \\
\text { good }\end{array}$ & $\begin{array}{c}\text { It is somewhat im- } \\
\text { proved. I have good } \\
\text { physical endurance, } \\
\text { can walk and drive } \\
\text { my auto long } \\
\text { distances, 200 miles } \\
\text { at one sitting } \\
\text { without fatigue }\end{array}$ & $\begin{array}{l}\text { Much } \\
\text { better }\end{array}$ & $\begin{array}{c}\text { Fully } \\
\text { as good }\end{array}$ & Good \\
\hline $\begin{array}{l}\text { Catheter life } \\
\text { for } 1 \text { year } \\
\text { before opera- } \\
\text { tion. Has } \\
\text { been seen } \\
\text { since above } \\
\text { answers were } \\
\text { received and } \\
\text { "dripping" is } \\
\text { insignificant }\end{array}$ & $\begin{array}{l}\text { Periodic } \\
\text { catheter } \\
\text { life for } \\
3 \text { years }\end{array}$ & $\begin{array}{c}\text { Coudé catheter broke } \\
\text { ofi in prostatic } \\
\text { urethra after opera- } \\
\text { tion and fragment } \\
\text { had to be removed } \\
\text { on 5th day per } \\
\text { perineum followed } \\
\text { by pronounced uri. } \\
\text { nary infection with } \\
\text { bilateral epididymitis; } \\
\text { had intermittent } \\
\text { catheter life for } \\
\text { 6 months before } \\
\text { operation }\end{array}$ & $\begin{array}{l}\text { Man of } \varepsilon 8 \\
\text { had a huge } \\
\text { prostate } \\
\text { and left } \\
\text { hospital } \\
\text { wearing a } \\
\text { urinal on } \\
\text { account of } \\
\text { dribbling. } \\
\text { Final result } \\
\text { is a com- } \\
\text { plete cure. } \\
\text { Had led cath- } \\
\text { eter life for } \\
5 \text { months }\end{array}$ & $\begin{array}{c}\text { Very large } \\
\text { prostate } \\
\text { in man of } \\
\text { 76. Cathe- } \\
\text { ter life } \\
\text { for } 6 \\
\text { months }\end{array}$ & $\begin{array}{c}\text { Complete } \\
\text { retention } \\
\text { and marked } \\
\text { vesical } \\
\text { distention } \\
\text { on admis- } \\
\text { sion, } 5 \text { weeks } \\
\text { preparatory } \\
\text { treatment. } \\
\text { Had led } \\
\text { catheter } \\
\text { life for } \\
3 \text { months }\end{array}$ \\
\hline
\end{tabular}




\begin{tabular}{|c|c|c|c|c|c|c|c|c|}
\hline 7 & 8 & 9 & 10 & 11 & 12 & 13 & 14 & Summary \\
\hline $\begin{array}{l}5 \text { to } 6 \\
\text { Yes }\end{array}$ & $\begin{array}{c}4 \\
\text { No }\end{array}$ & $\begin{array}{l}\text { 4-5 } \\
\text { Yes }\end{array}$ & $\begin{array}{c}3 \text { to } 4 \mathrm{hrs} \text {. } \\
\text { Yes }\end{array}$ & $\begin{array}{l}4 \text { to } 5 \\
\text { No }\end{array}$ & $\begin{array}{c}3 \text { to } 4 \text { times } \\
\text { Yes }\end{array}$ & $\begin{array}{c}\text { About } \\
\text { every } 4 \\
\text { hours } \\
\text { Yes }\end{array}$ & $\begin{array}{c}4 \text { times } \\
\text { Yes }\end{array}$ & $\begin{array}{l}4 \text { to } 5 \\
\text { No, } 1 \\
\text { Yes, 11 }\end{array}$ \\
\hline $\begin{array}{c}\text { Always once } \\
\text { sometimes } \\
\text { twice } \\
\text { 6a.m. }\end{array}$ & $\ldots \ldots$ & $\begin{array}{c}2-3 \text {, get up } \\
\text { for bowel } \\
\text { movement } \\
\text { void at } \\
\text { same time } \\
\text {....... }\end{array}$ & $\begin{array}{l}3 \text { to } 4 \\
\text { times }\end{array}$ & $\ldots \ldots$ & $\begin{array}{c}6 \text { to } 7 \\
\ldots \ldots \ldots\end{array}$ & 12 and 4 & $2-5$ a. $\mathrm{m}$ & 2 \\
\hline No & No & No & I do & No & No & No & No & No, 13 \\
\hline No & No & No & No & No & No & No & Occasion- & No, 12 \\
\hline $\begin{array}{l}\text { No } \\
\text { Slight in } \\
\text { morning } \\
\text { Yes } \\
\text { No }\end{array}$ & $\begin{array}{c}\text { No } \\
\text { Slight } \\
\text { Yes } \\
\text { No }\end{array}$ & $\begin{array}{c}\text { No } \\
\text { No } \\
\ldots \ldots \\
\ldots \ldots\end{array}$ & $\begin{array}{l}\text { No } \\
\text { Yes } \\
\text { No } \\
\text { Yes }\end{array}$ & $\begin{array}{c}\text { No } \\
\text { No } \\
\ldots \ldots \ldots \\
\ldots \ldots \ldots\end{array}$ & $\begin{array}{c}\text { No } \\
\text { No } \\
\ldots \ldots \ldots \ldots \\
\ldots \ldots \ldots \ldots\end{array}$ & $\begin{array}{l}\text { No } \\
\text { No } \\
\ldots \ldots \\
\ldots \ldots\end{array}$ & $\begin{array}{l}\text { No } \\
\text { No } \\
\ldots \ldots \\
\ldots \ldots\end{array}$ & $\begin{array}{l}\text { No, } 14 \\
\text { No, } 9 \\
\text { Yes, } 5 \\
4 \\
3\end{array}$ \\
\hline $\begin{array}{l}\begin{array}{c}\text { Yes, very } \\
\text { good } \\
\text { Yes } \\
\ldots\end{array} \\
\ldots .\end{array}$ & $\begin{array}{c}\text { Yes } \\
\text { Yes } \\
\ldots \ldots \ldots\end{array}$ & $\begin{array}{c}\text { Yes } \\
\text { Occasion- } \\
\text { ally }\end{array}$ & \begin{tabular}{|} 
Fairly \\
good \\
Cloudy, \\
strong odor
\end{tabular} & $\begin{array}{c}\text { Yes } \\
\text { Yes } \\
\ldots . .\end{array}$ & $\begin{array}{c}\text { Yes } \\
\text { Yes } \\
\ldots \ldots \ldots \ldots\end{array}$ & $\begin{array}{c}\begin{array}{c}\text { Yes, very } \\
\text { good }\end{array} \\
\text { Y.... }\end{array}$ & $\begin{array}{c}\text { Yes } \\
\text { Yes } \\
\cdots . . .\end{array}$ & $\begin{array}{c}\text { Yes, } 14 \\
10 \\
4\end{array}$ \\
\hline $\begin{array}{c}\text { Sometimes } \\
\text { Partial }\end{array}$ & $\begin{array}{l}\text { Yes } \\
\text { Few }\end{array}$ & $\cdots \cdots$ & $\begin{array}{c}\text { No } \\
\text { Very little }\end{array}$ & $\begin{array}{l}\text { No } \\
\text { No }\end{array}$ & $\begin{array}{c}\cdots \cdots \cdots \\
\text { No }\end{array}$ & $\begin{array}{c}\text { Practi- } \\
\text { cally none } \\
\text { No }\end{array}$ & $\begin{array}{l}\text { Yes } \\
\text { Yes }\end{array}$ & $\begin{array}{l}9 \\
6\end{array}$ \\
\hline $\begin{array}{l}\text { No } \\
\text { Yes }\end{array}$ & $\begin{array}{c}\text { No } \\
\ldots \ldots \cdots\end{array}$ & $\begin{array}{l}\cdots \cdots \\
\ldots \cdots\end{array}$ & $\begin{array}{l}\text { No } \\
\text { Yes }\end{array}$ & $\cdots \cdots$ & $\begin{array}{l}\cdots \cdots \cdots \\
\ldots \ldots \cdots\end{array}$ & $\begin{array}{l}\ldots \ldots \\
\ldots \ldots\end{array}$ & $\begin{array}{c}\text { Yes } \\
\ldots . . .\end{array}$ & $\begin{array}{c}\text { No, } 4 \\
\text { Tes, } 3\end{array}$ \\
\hline No & Yes & $\ldots \ldots$ & No & No & No & No & Yes & 5 \\
\hline No & $\ldots \ldots \ldots$ & $\ldots \ldots$ & No & No & No & No & $\ldots \ldots$ & 2 \\
\hline $\begin{array}{c}\ldots \ldots \ldots \\
\ldots \ldots \ldots \\
\text { None } \\
\text { Not attempted. } \\
\text { No intereourse } \\
2 \text { yrg. before } \\
\text { operation }\end{array}$ & $\begin{array}{c}\text { Once or twice } \\
\text { a week } \\
\text { No } \\
\text { No }\end{array}$ & $\begin{array}{l}\cdots \cdots \\
\ldots \ldots \\
\ldots \cdots \\
\cdots \cdots\end{array}$ & $\begin{array}{c}\ldots \ldots \\
\cdots \cdots \\
\ddot{\mathbf{Y}} \ddot{\mathrm{es}}\end{array}$ & $\begin{array}{c}\text { Not at- } \\
\text { tempted } \\
\ldots \ldots \\
\ldots \ldots\end{array}$ & 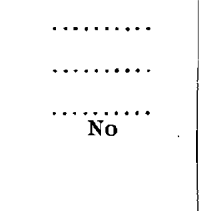 & $\begin{array}{c}\text { Yes } \\
\ldots \ldots \\
\ldots \ldots \\
\ldots \ldots\end{array}$ & $\begin{array}{c}\text {..... } \\
\text { Once every } \\
\text { two weeks } \\
\text { Yes } \\
\text { Yes } \\
\text { (watery } \\
\text { nature) }\end{array}$ & $\begin{array}{l}6 \\
2 \\
3 \\
3\end{array}$ \\
\hline Yes & $\begin{array}{l}\text { Yes. but in void- } \\
\text { ing the urine comes } \\
\text { freely for a while } \\
\text { but sometimes } \\
\text { shuts it off before } \\
\text { I get through and } \\
\text { there is a dribbling } \\
\text { for a time }\end{array}$ & Yes & Yes & Yes & Yes & Yes & Yes & 14 \\
\hline $\begin{array}{c}\text { Excellent } \\
\text { much better } \\
\text { than before } \\
\text { operation }\end{array}$ & $\begin{array}{l}\text { Decidedly } \\
\text { better }\end{array}$ & Improved & $\begin{array}{c}\text { Much } \\
\text { better }\end{array}$ & $\begin{array}{l}\text { Greatly } \\
\text { improved }\end{array}$ & $\begin{array}{l}\text { My health is as } \\
\text { good as before } \\
\text { operation, my } \\
\text { only trouble is } \\
\text { that my legs } \\
\text { are very weak } \\
\text { from thigh } \\
\text { to knee }\end{array}$ & $\begin{array}{c}\text { Much } \\
\text { improved }\end{array}$ & $\begin{array}{l}\text { Very } \\
\text { much } \\
\text { improved }\end{array}$ & $\begin{array}{l}\text { Improved in } 12 \\
\text { As good in } 2\end{array}$ \\
\hline $\begin{array}{l}\text { Preliminary } \\
\text { cystotomy and } \\
\text { removal of } \\
\text { large vesical } \\
\text { calculus. } \\
\text { Periodic eathe- } \\
\text { terization for } \\
3 \text { months }\end{array}$ & $\begin{array}{l}\text { This man has sicce } \\
\text { been cystoscoped } \\
\text { and a small tag } \\
\text { of mucous mem- } \\
\text { brane at the vesi- } \\
\text { cal margin re- } \\
\text { moved by fulgura. } \\
\text { tion with complete } \\
\text { relief of dribbling } \\
\text { and hesitancy. } \\
\text { Had complete re- } \\
\text { tention before } \\
\text { operatlon and } \\
\text { used catheter } \\
3 \text { months }\end{array}$ & $\begin{array}{l}\text { This patient } \\
\text { has senile } \\
\text { dementia } \\
\text { which was } \\
\text { present } \\
\text { before } \\
\text { opera- } \\
\text { tion }\end{array}$ & $\begin{array}{c}\text { Had pro- } \\
\text { nounced } \\
\text { pyuria and } \\
\text { bilateral } \\
\text { pyelo- } \\
\text { nephritis } \\
\text { with eysti- } \\
\text { tis before } \\
\text { operation }\end{array}$ & $\begin{array}{l}\text { Catheter } \\
\text { life for } \\
1 \text { year } \\
\text { before } \\
\text { opera- } \\
\text { tion }\end{array}$ & $\begin{array}{l}\text { This patient has } \\
\text { a chronic ne- } \\
\text { phritis and } \\
\text { cardiac decom- } \\
\text { pensation. } \\
\text { Under prepara- } \\
\text { tion for } 6 \text { weeks. } \\
\text { Had periodieal } \\
\text { incontinence on } \\
\text { admission }\end{array}$ & $\begin{array}{c}\text { Catheter } \\
\text { life for } 4 \\
\text { months } \\
\text { before } \\
\text { opera- } \\
\text { tion }\end{array}$ & $\begin{array}{c}\text { Intermit- } \\
\text { tent } \\
\text { catheter } \\
\text { life for } 6 \\
\text { months }\end{array}$ & $\begin{array}{l}\text { All were ad- } \\
\text { vanced cases of } \\
\text { prostatism } \\
\text { and had been } \\
\text { compelled to } \\
\text { use a catheter } \\
\text { intermittently } \\
\text { or regularly }\end{array}$ \\
\hline
\end{tabular}


montane portion, so that when this is removed later, with the hyperplastic mass, tearing of the vermontanum and consequent disturbance of the ejaculatory ducts do not occur. Before we appreciated the importance of the deep incision in this supramontane portion of the prostatic urethra, in two or three instances the verumontanum with the ends of the ejaculatory ducts was torn away with the hyperplastic mass (Figs. 10 and 11). These experiences lead us to believe that the colliculus and the terminal portions of the ejaculatory ducts are often similarly removed in suprapubic en masse enucleation.

Attempts to preserve the membranous coat of the prostatic urethra when one follows Young's technic in patients with big prostates are usually unsuccessful. In view of the deep sulci and the distortion and elongation of the prostatic urethra in these cases, preservation seems undesirable. So much loose unattached mucous membrane may be so folded or plicated that it forms obstruction to instrumentation as well as urination and prevents good structural healing. The ability of urethral mucosa to repair is familiar to every urologist who can readily recall extensive resections of the urethra in performing external urethrotomies and the rapidity with which these gaps fill in. Complete divulsion of the prostatic urethra is universally practiced in suprapubic enucleation, and it ought not to be more mutilating when done perineally under direct control of the eye. However, is such complete divulsion of the prostatic urethra responsible for the large cavity formation so much more frequently encountered after suprapubic prostatectomy? This is doubtful. Cavity formation is more readily accounted for by the difference in methods of packing for the control of hemorrhage and the anatomic difference of enucleation. Suprapubically, the whole enlargement must be shelled out through the internal vesical sphincter, and often the vesical mucosa is stripped back from the bladder wall. Perineally, only the intravesical portion of the gland is drawn back through the sphincter, which is undisturbed surgically. The suprapubic operator packs the cavity full from above, elongating and exaggerating the prostatic space and often adding to the separation of the vesical margin from the prostatic cavity. The perineal operator packs lightly and partially from below and relies largely on infraprostatic compression for hemostasis, which tends to foreshorten the prostatic space and obliterate the cavity. Repacking suprapubically only exaggerates and prolongs the existence of the cavity. Repacking through the perineum is almost invariably an infraprostatic compression with further obliteration of the cavity. In none of our twenty-five cases of en masse enucleation by prostatic urethral divulsion through the perineum has cavity formation ever occurred.

The great advantage of this modification is that it secures a more complete removal of the hyperplasia. Ring type enlargements are quite frequent, and even if they are not typical, there 
is some fusion of tissue between the separate lobes (Fig. 13), and it is an easy and no uncommon matter to leave behind small or large spheroids at the region of separation of these lobes when they are removed separately or in portions. The smaller fibrous enlargements, particularly, tend to be ring type, and resection of such enlargements is extremely difficult and incomplete when performed by segments, but much simpler and more certain when removed on bloc (Fig. 12). The absence of a pseudocapsule makes such removal very unsatisfactory suprapubically, but is an insignificant factor perineally because of the good exposure obtained by laying the posterior urethra wide open, with the inverted $\mathrm{V}$ type incision. There is no comparison between the accuracy and ease of en masse enucleation by the two methods. Perineally, with blunt dissector, scissors or knife, one can perform an accurate surgical resection under direct control of the eye.

The cases that have been treated by this modification have been reported elsewhere. ${ }^{5}$ The importance and perfection of certain details of operative technic and of methods of drainage and packing were not fully realized in the first ten or twelve cases. In the accompanying table, however, the actual answers to a questionnaire are given by these earlier patients in whom one year or more has elapsed since operation and in all of whom radical en masse enucleation was performed. All fourteen state that they are cured of prostatism; two have complete preservation of sexual function, and in five others, it is diminished and partial, untried in seven. ${ }^{6}$

The immediate results of the more recent twelve cases, in which the perfected details of the procedure were applied, have all been completely satisfactory. The average stay in the hospital after operation has been twenty-three days, and the average time for closure of the perineal fistula has been five days. Seven cases have closed to all practical purposes by first intention, there being no urinary leakage after a few hours from the time of removal of the perineal drain. In two cases, however, owing to urethral and urinary infection, the urethral catheter had to be removed early and closure was delayed, and by granulation being complete on the fourteenth and nineteenth day, respectively. One patient whose perineum healed by first intention had quite a profuse secondary hemorrhage on the ninth day, which acted and was treated similarly to the hemorrhage following a punch operation. The convalescence was uneventful in six cases; two patients

5. Cases 30 to 50, inclusive, and Case 11 of Group A; Cases 38, 39 and 40 of Group B, "Suprapubic Versus Perineal Prostatectomy" read at the Montreal meeting of the American Urological Association, June 2, 1921.

6. Before operation, sexual life was stated as normal in only four of the fourteen cases; the other ten having markedly diminished, lost or unknown, because untried, sexual ability. 
had troublesome cardiac insufficiency, one renal insufficiency, two a mild phlebitis and six rather marked pyuria, with evidence of urinary infection. Only two patients had epididymitis after operation. The general and functional result indicates a complete cure in all these recent cases. Five patients have stated that their sexual life was normal before operation. It was lost or absent in two, diminished in three and not stated in two. It is already known that in three, normal sexual life has been resumed.

\section{CONCLUSIONS}

Failure of complete restoration of function after prostatectomy is commonly associated with structural defects. Suprapubically, the common defect is the persistence of a large prostatic cavity. Perineally, the defect is commonly due to nodules or lobular remnants from incomplete or irregular enucleation. It is possible to perform a onepiece perineal prostatectomy, remove the hyperplasia with the associated prostatic urethra completely and cleanly, and at the same time surgically preserve both vesical sphincters and the colliculus and ejaculatory ducts. The structural result in such a radical procedure is surprisingly good, and less apt to be defective than when done suprapubically. A large prostatic cavity has never resulted, and the prostatic urethra becomes quickly reestablished. The functional results have been entirely satisfactory in twenty-five cases. 